\title{
Recovery of biological soil crusts following wildfire in Idaho
}

\author{
JULIE H. HILTY, DAVID J. ELDRIDGE, ROGER ROSENTRETER, MARCIA C. WICKLOW-HOWARD, AND \\ MIKE PELLANT
}

Authors are Botanist, Bureau of Land Management, 400 West F St. Shoshone, Ida., 83352, email: Julie_Hilty@blm.gov; Senior Research Scientist, Department of Land and Water Conservation, c/- School of Biological, Earth and Environmental Sciences, University of NSW, Sydney, 2052, NSW, Australia; Botanist, Bureau of Land Management, 1387 S. Vinnell Way, Boise, Ida. 83709; Professor, Biology Department, Boise State University, 1910 University Drive, Boise, Ida. 83725; Great Basin Restoration Initiative Coordinator, Bureau of Land Management, 1387 S. Vinnell Way, Boise, Idaho, 83709. At the time of the research, the senior author was a MSc candidate in the Biology Department, Boise State University, Boise, Ida.

Address for correspondence: Bureau of Land Management, 400 West F St. Shoshone, Ida. 83352

\section{Abstract}

Invasion of sagebrush steppe by exotic annual grasses has modified the structure of shrubland communities over much of the western United States by increasing fuel loads and therefore the frequency of wildfire. Active revegetation with perennial species that encourage the growth of biological soil crusts is critical on many burned sites to prevent dominance by exotic, weedy vegetation. However, active regeneration is likely to lead to a disruption of the soil surface and impact adversely on soil crust communities which are important for stability and functioning of shrub communities. We examined the recovery of biological soil crusts on sagebrush steppe following wildfire. Burning resulted in significantly reduced shrub cover and enhanced annual grass and annual forb cover compared with unburned sites. Burning also resulted in substantially reduced diversity and richness of crust taxa, increased cover of short mosses, but reduced cover of lichens and tall mosses growing on the shrub hummocks. Postfire recovery of perennial grasses and biological soil crusts was greatest on seeded sites compared with unseeded sites dominated by exotic grasses, despite the disturbance associated with the rangeland seeding treatment. Our results indicate that seeding is necessary to facilitate recovery of biological soil crusts and hasten the development of the perennial component of the shrubland and therefore increase landscape structure. These findings suggest that seeding perennial grasses and resting from livestock grazing reduces exotic annual grasses after fire and benefits native mosses.

Key Words: cryptogamic crust, microphytic crust, burning, sagebrush, moss, lichen

Biological soil crusts (also known as cryptogamic, microbiotic or microphytic soil crusts) are complex associations of bryophytes (mosses and liverworts), lichens, cyanobacteria, microfungi, algae and bacteria occurring as a thin layer on and just beneath the soil surface in arid and semi-arid landscapes (West 1990). The relative proportions of different groups of organisms comprising biological crusts are influenced by soil

We thank Mark Seyfried for advice on study design, Jim Hilty for assistance in the field, Laura Bond and Terry Koen for statistical advice, and Larry St Clair and three anonymous referees for comments on the manuscript. The study was funded by the USDI Bureau of Land Management, Department of Defense Legacy Program, and the Northwest Science Association. USDA Agricultural Research Service, Northwest Watershed Research Center, provided facilities, equipment and technical assistance for soil analyses.

Manuscript accepted 10 May 03.

\section{Resumen}

La invasión de las estepas de "Sagebrush" por zacates anuales exóticos han modificado la estructura de comunidades de matorral de gran parte del oeste de Estados Unidos al incrementar las cargas de combustible, $y$ por lo tanto la frecuencia de fuegos naturales. La revegetación activa con especies perennes que fomentan el crecimiento de costras biológicas del suelo es critico en muchos sitios quemados para prevenir el dominio de la vegetación exótica de malezas. Sin embargo, es probable que la regeneración activa conduzca a la disrupción de la superficie del suelo e impacte adversamente las comunidades de la costra del suelo, las cuales son importantes para la estabilidad y funcionamiento de las comunidades de arbustos. Examinamos al recuperación de las costras biológicas del suelo en una estepa de "Sagebrush" después de un fuego no controlado. La quema resultó en una reducción significativa de la cobertura de arbustos y aumentó la cobertura de zacates y hierbas anuales en comparación con los sitios no quemados. La quema también resulto en una diversidad y riqueza de taxas de la costra substancialmente reducida, incrementó la cobertura de musgos cortos, pero redujo la cobertura de líquenes y musgos altos que crecen en arbustos agrupados. La recuperación de los zacates perennes y la costra biológica después del fuego fue mayor en los sitios sembrados en comparación con los sitios no sembrados dominados por zacates exóticos, a pesar del disturbio asociado con los tratamiento de siembra del pastizal. Nuestros resultados indican que la siembra es necesaria para facilitar la recuperación de la costra biológica del suelo y acelerar el desarrollo del componente perenne del matorral y por lo tanto incrementar la estructura del paisaje. Estos hallazgos sugieren que la siembra de zacates perennes y el descanso de la vegetación al no apacentar ganado reduce los zacates anuales exóticos después del fuego y beneficia los musgos nativos.

characteristics and climatic patterns, causing biological crust composition to vary considerably between and within geographic regions.

Biological crusts are a conspicuous feature of many arid and semi-arid landscapes, fulfilling some of the functions performed by vascular plants in more mesic environments. At the most basic level, many components of biological crusts are photosynthetic cover, fixing carbon from the atmosphere and sequestering organic carbon into the soil (Beymer and Klopatek 1991). Biological crusts bind and stabilize soil surfaces, buffering them from water and wind erosion (Williams et al. 1995, Eldridge 1998, Leys and 
Eldridge 1998). Many cyanobacteria and all cyanolichens associated with crusts also fix atmospheric nitrogen, and may enhance the establishment and survival of vascular plant seedlings by increasing the availability of essential mineral nutrients (Harper and Belnap 2001). Rough crust surfaces also produce suitable microsites for germination, establishment and survival of vascular plant seedlings (Lesica and Shelly 1992, Harper and Pendleton 1993). Over the past decade land managers in some arid and semi-arid regions have begun to integrate biological crusts into assessments of ecosystem function and stability (see Rosentreter and Eldridge 2002).

On the Snake River Plain, at the northern extent of the Great Basin, these shrubsteppe communities contain biological crusts dominated by mosses and lichens which contribute to an undulating and pedicelled microtopography in the spaces between perennial plants. Plant communities dominated by the shrub Artemisia tridentata Nutt. ssp. wyomingensis Beetle \& Young and perennial caespitose grasses are common throughout the Great Basin in western North America. On sites with low levels of livestock or recreational use, biological crusts may occupy much of the soil surface that is not covered by vascular plants or litter (Rosentreter and Belnap 2001).

Composition and structure of many native shrub-steppe communities have been irreversibly modified by extensive and uncontrolled livestock impact since the late nineteenth and early twentieth centuries. Grazing related problems have been further complicated by the invasion of annual Eurasian weeds (Mack 1981). Annual grasses, primarily Bromus tectorum L. and Taeniatherum caput-medusae ssp. asperum L. have increased fine-fuel densities within plant communities, and homogenized fuel distribution across the landscape. Increased wildfire frequencies have resulted in conversion of much of the Artemisia shrub-steppe to annual grasslands which in turn burn at intervals of less than 10 years (Whisenant 1990). Consequently, soil crusts at these sites have been affected by changes in species composition, grazing and fire cycles.

Burning results in loss of biological crust cover and biomass with the extent of damage depending on fire intensity, the frequency of reburning, and the nature of the resulting patchwork mosaic of burned and unburned areas (Callison et al. 1985, Schulten 1985, Greene et al. 1990, Youtie et al. 1999, Johansen 2001). Depending on the intensity of fires, biological crust com- ponents such as fungal hyphae, algal and cyanobacterial filaments and moss and lichen rhizines may persist for some time after burning. This might be responsible for reducing erosion on the burned site while the biological crust and vascular vegetation begin to recover. However, repeated burning may completely destroy soil crust structures (Greene et al. 1990).

Other disturbances, including those associated with restoration methods, can also destroy soil crusts. On sites where the potential for exotic annual species invasion and soil erosion is high, active revegetation may be required to avoid irreversible site degradation after wildfire. In the process of revegetation, seeding with rangeland drills may result in fragmentation, overturning or covering of the biological crust, potentially hindering the recovery of the fire-damaged crust. Disturbance by livestock (Kleiner and Harper 1972, Brotherson et al. 1983, Warren and Eldridge 2001) also reduces biological crust cover and increases the potential for soil loss due to wind and water erosion. Nutrient and hydrologic cycles, surface temperatures, and community structure and function can be irreversibly altered by soil surface disturbance, resulting in accelerated desertification of semi-arid and arid landscapes (Rosentreter and Eldridge 2002).

Crust recovery rates vary, and range from 2-5 years for partial regeneration of algal crusts to up to 200 years or more for moss and lichen crusts (Callison et al. 1985, Johansen 2001). However, the presence of a crust does not imply complete recovery as some elements in the crust may still not have recovered and ecosystem function may still be impaired (J. Belnap personal communication, 2003). Factors that influence recovery rates include the type of organisms dominating the crust, the size and severity of the disturbance, and the proximity of inoculant sources to the disturbed area. Biological crusts are metabolically active only when moist, therefore the timing of precipitation events following the disturbance also impacts recovery (Belnap and Eldridge 2001).

In this paper we report on a study comparing the recovery of biological soil crusts following wildfire in unburned Wyoming big sagebrush communities with adjacent burned areas with and without post-fire seeding. The objective was to examine relationships between recovery of the soil crust community and recovery of various attributes of the vascular plant community.

\section{Methods}

\section{The study area}

The study area was located in the Wyoming big sagebrush shrub-steppe community on the Snake River Plain south of Boise, Ida. Three sites, Kuna Butte East (approximately $4.8 \mathrm{~km}$ south of Kuna, Ida, $43^{\circ} 27^{\prime} \mathrm{N}, 116^{\circ} 26^{\prime} \mathrm{W}, 884-914 \mathrm{~m}$ above sea level (asl)), Kuna Butte West (approximately $4.8 \mathrm{~km}$ south of Kuna, Ida., $43^{\circ} 27^{\prime} \mathrm{N}$, $116^{\circ} 27^{\prime} \mathrm{W}, 945 \mathrm{~m}$ asl) and Rattlesnake Creek (approximately $4.8 \mathrm{~km}$ northeast of Mountain Home, Ida., along U.S. Route 20, $43^{\circ} 10^{\prime} \mathrm{N}, 115^{\circ} 37^{\prime} \mathrm{W}, 1005-1035 \mathrm{~m}$ asl) were selected for the study. All sites were located on public lands administered by the Bureau of Land Management (BLM). The 3 sites had relatively flat topography and a similar fire history, having been burned extensively and with similar intensities between 1980 and 1983, approximately a decade prior to the commencement of this study (Kochert and Pellant 1996). Sites that were selected had about a decade of recovery from burning.

Each site contained areas of 1) unburned, 2) burned and seeded, and 3) burned and unseeded shrub-steppe. The unburned and unseeded (termed 'control') sites supported Wyoming big sagebrush with a perennial herbaceous understory dominated primarily by the native species Sandberg bluegrass (Poa secunda J. Presl.) and bottlebrush squirreltail [Elymus elymoides (Raf.) Swezey]. Burned sites which had been revegetated (termed burned-seeded) were seeded with perennial grasses using a rangeland drill during the fall following burning. Adjacent burned and unseeded (termed ëburnedunseededí) sites were also present. All sites used in this study showed evidence of historic overgrazing, as indicated by the absence of 2 important perennial grasses for this geographic area: bluebunch wheatgrass [Pseudoroegneria spicata (Pursh) A. Love] and Thurberís needlegrass [Achnatherum thurberianum (Piper) Barkworth]. Following burning and seeding, these sites were rested from domestic livestock use.

Soils in the area are predominantly Aridisols, formed on loess and sedimentary deposits covering basalt lava flows (Hironaka et al. 1983). The climate is semi-arid, with hot, dry summers and cool, wet winters. Annual precipitation ranges from $178-305 \mathrm{~mm}$, with less than $35 \%$ of the moisture occurring between April and September (Hironaka et al. 1983). Mean daily temperatures range from $-1^{\circ} \mathrm{C}$ in January to $24^{\circ} \mathrm{C}$ in July. In general, biological soil crusts in the unburned sage- 
brush stands were dominated by crustose, squamulose and fruticose lichens and Pottiaceous mosses (Kaltenecker et al. 1999). Mosses formed short turfs in the interspaces with lichens interspersed and growing on top of the moss. Tall moss (Tortula ruralis (Hedw.) Gaertn. et al. commonly forms thick mats under sagebrush canopies in this shrub-steppe. In the burned sites, crusts were completely destroyed in all but those sites which failed to carry a fire because of lower fuel levels.

\section{Field sampling}

For each combination of the 3 sites by 3 treatments (control, burned-seeded, burned-unseeded), we established six, 20 $\mathrm{m}$ transects, resulting in a total of 54 transects for the study. Each treatment area was stratified to include a relatively homogeneous stand of vegetation 1 to 2 ha in area, and transects were randomly (and permanently) located within the stands.

We used the line-intercept method (Canfield 1941) to measure the cover of various plant and soil crust components. A tape was laid along the transect as close to the ground as possible to ensure accurate measurement of ground cover. If the soil surface was dry, all transects were moistened with a spray of water to optimize detection of biological crusts. During April and May 1994, the following components were measured along each transect: 1) projected foliage cover (i.e. the projected cover of the canopy) of all vascular plant species, 2) cover of the visible elements of biological soil crust, i.e. lichen, moss and liverwort (classified by morphological group) but excluding cyanobacteria, 3) cover of litter, 4) cover of rock, and 5) cover of bare ground (excluding cyanobacteria). Litter was divided into 2 categories: persistent litter (large twigs and woody debris, deep accumulations of leaves under shrubs, or layers of Bromus tectorum $>10 \mathrm{~mm}$ deep) and non-persistent litter (small twigs, leaves and other plant debris scattered on the ground, but not forming a thick continuous mat). Standing (non-detached) litter was included in the assessment of vascular plant cover.

Vascular plants were later combined into the following life form groups for analysis: shrubs, perennial grasses, perennial forbs, annual grasses (primarily exotic species), and exotic annual forbs. At the time of field measurements, most native annual forbs were dead and contributed very little cover. Consequently, they were not included in the analyses.

Biological soil crust taxa recorded along the transects were assigned to a particular morphological group (short moss, tall moss, squamulose lichen, crustose lichen, gelatinous lichen or foliose-fruticose lichen). These groups enabled us to use data collected directly from the field rather than rely on laboratory-based taxonomy which is inefficient and often requires destructive sampling (Eldridge and Rosentreter 1999). However, each site ( 1 ha) was systematically searched and voucher specimens for all bryophytes and lichens were collected.

\section{Soil sampling}

Soil samples were analyzed to determine soil texture, electrical conductivity and $\mathrm{pH}$. Twenty soil cores, $50 \mathrm{~mm}$ diameter by $50 \mathrm{~mm}$ deep, were collected at 1 meter intervals along each transect and combined to form a composite sample. Electrical conductivity and $\mathrm{pH}$ were determined on a 1:1 soil-water extract using 3 sub-samples per transect. Electrical conductivity was determined using a YSI model 35 conductance meter. All readings were corrected to $25^{\circ} \mathrm{C}$. An Orion model 710A benchtop $\mathrm{pH} / \mathrm{ISE}$ meter was used to determine $\mathrm{pH}$. Texture of the $<2 \mathrm{~mm}$ fraction was determined using the hydrometer method (Gee and Bauder 1986).

\section{Statistical analyses}

Two-way analysis of variance (ANOVA) was used to test for differences in the percent cover of various components between the 3 treatments after checking for homogeneity of variance using Levene's Test (Minitab 1997). The site variable was treated as a random effect and treatment as a fixed effect in the balanced model. Post-hoc comparisons of treatment means were performed using Least Significant Difference (LSD) tests using Minitab (1997).

A matrix comprising presence-absence data of each soil crust taxa (by genus and species) by 3 treatments (each with 3 replicates) was converted to a similarity matrix using the Bray-Curtis similarity coefficients contained within the PRIMER (Version 4) statistical package (Clarke and Warwick, 1994). This similarity matrix was subjected to non-metric MultiDimensional Scaling (MDS) using one of the PRIMER (Version 4) routines to determine whether sites of a particular treatment were characterized by a unique suite of soil crust taxa. Hypothesis tests of differences between the 3 groups (control, burned-seeded, burned-unseeded), defined a priori, were performed using ANOSIM, which is comparable to a distribution-free two-way ANOVA (Clarke 1993). Using a number of random permutations on the similarity matrix, ANOSIM produces a test statistic (Global R) with a significance level which we used to determine whether the cover of the surfaces varied significantly between the 3 treatments.

\section{Results and Discussion}

\section{Surface soil characteristics}

Across all sites, soils tended to be finetextured silts and loams with low values of electrical conductivity and neutral $\mathrm{pH}$ (Table 1). Silt levels were significantly higher on the burned-seeded plots compared with the other plots $\left(\mathrm{F}_{1,51}=4.97, \mathrm{P}\right.$ $=0.011)$, and clay contents were significantly higher on the burned-unseeded plots compared with the other plots $\left(\mathrm{F}_{1,51}=\right.$ 5.73, $\mathrm{P}=0.006$; Table 1). Increased silt levels may be due to soil disturbance during the operation of the drill seeder and the capture of silt in the upper layers, or conceivably, increased capture of silt in the burnedseeded plots due to grasses and a greater cover of crust. We are unable however to explain higher levels of clay on the burnedunseeded plots. There were no significant differences in electrical conductivity, $\mathrm{pH}$ or percentage of sand between the 3 treatments (P > 0.05; Table 1).

In general, soil properties were highly variable within all sites, but this variability tended to increase when the soils were seeded. Much of the soil variability is related to the inherent landscape structure, particularly between shrub-interspace and disturbed-undisturbed patches (Reid et al. 1999). Patchiness at small spatial scales can have pronounced effects on soil physical and chemical properties, particularly between shrub and interspace patches (Bergkamp 1998).

\section{Vascular plant cover}

Apart from the obvious loss of shrubs in the burned plots (Table 1), there were other substantial changes in the structure and composition of the vascular plant community which probably influenced the post-fire recovery of the biological crust. Exotic annual grasses, particularly Bromus tectorum, dominated the burned-unseeded plots, while cover in both the burned-seeded and control plots was sparse. The sparse cover of shrubs in the burned-seeded plots was compensated by the significantly greater cover of perennial grasses, particularly Agropyron spp. and Elymus spp. $(\mathrm{P}<0.001$, Table 1$)$. Perennial grass clumps are known to create microstructure 
Table 1. Soil physical characteristics and cover components (\%) for the 3 treatments. SE = standard error of the mean. Different letters within a row indicate a significant difference at $\mathbf{P}<$ 0.05.

\begin{tabular}{|c|c|c|c|c|c|c|}
\hline \multirow[t]{2}{*}{ Attribute } & \multicolumn{2}{|c|}{ Control } & \multicolumn{2}{|c|}{ Burned-unseeded } & \multicolumn{2}{|c|}{ Burned-seeded } \\
\hline & Mean & SE & Mean & $\mathrm{SE}$ & Mean & SE \\
\hline $\mathrm{EC}\left(\mathrm{dSm} \mathrm{m}^{-1}\right)$ & $0.21^{\mathrm{a}}$ & 0.01 & $0.24^{\mathrm{a}}$ & 0.01 & $0.24^{\mathrm{a}}$ & 0.02 \\
\hline $\mathrm{pH}$ (water) & $6.74^{\mathrm{a}}$ & 0.04 & $6.92^{\mathrm{a}}$ & 0.03 & $6.98^{\mathrm{a}}$ & 0.03 \\
\hline$\%$ sand & $30.7^{\mathrm{a}}$ & 0.97 & $33.5^{\mathrm{a}}$ & 0.77 & $35.0^{\mathrm{a}}$ & 1.82 \\
\hline$\%$ silt & $62.2^{\mathrm{a}}$ & 0.85 & $57.8^{b}$ & 0.82 & $57.1^{b}$ & 1.79 \\
\hline$\%$ clay & $7.1^{\mathrm{a}}$ & 0.41 & $8.7^{b}$ & 0.24 & $7.9^{\mathrm{a}}$ & 0.32 \\
\hline Shrub & $30.7^{\mathrm{a}}$ & 1.62 & $0.0^{\mathrm{b}}$ & 0.00 & $0.1^{b}$ & 0.04 \\
\hline Perennial grass & $13.8^{\mathrm{a}}$ & 1.32 & $4.2^{\mathrm{a}}$ & 1.04 & $36.6^{\mathrm{b}}$ & 3.17 \\
\hline Perennial forb & $0.2^{\mathrm{a}}$ & 0.08 & $0.2^{\mathrm{a}}$ & 0.17 & $0.6^{\mathrm{a}}$ & 0.27 \\
\hline Annual grass & $0.1^{\mathrm{a}}$ & 0.06 & $59.4^{\mathrm{b}}$ & 5.92 & $1.3^{\mathrm{a}}$ & 0.66 \\
\hline Annual forb & $0.0^{\mathrm{a}}$ & 0.00 & $36.7^{b}$ & 5.10 & $0.1^{\mathrm{a}}$ & 0.67 \\
\hline Bare ground & $9.0^{\mathrm{a}}$ & 1.12 & $7.3^{\mathrm{a}}$ & 1.93 & $28.7^{b}$ & 3.63 \\
\hline Rock & $3.9^{\mathrm{a}}$ & 1.33 & $3.4^{\mathrm{a}}$ & 0.89 & $3.7^{\mathrm{a}}$ & 1.03 \\
\hline Persistent litter & $25.3^{\mathrm{a}}$ & 5.51 & $67.4^{\mathrm{b}}$ & 8.19 & $11.3^{\mathrm{a}}$ & 2.37 \\
\hline Non-persistent litter & $13.5^{\mathrm{a}}$ & 2.64 & $7.5^{\mathrm{b}}$ & 3.41 & $12.7^{\mathrm{a}}$ & 2.64 \\
\hline Total litter & $38.8^{\mathrm{a}}$ & 3.34 & $74.9^{\mathrm{b}}$ & 3.59 & $24.0^{\mathrm{a}}$ & 2.19 \\
\hline
\end{tabular}

in the landscape, influencing local microclimate and creating a microclimate conducive to biological soil crusts (Longton 1992). Reestablishment of perennial grass clumps and recovery of biological soil crusts occurred together and were correlated with a reduced cover of the invasive exotic Bromus tectorum (Table 1).

Differences in the vascular plant community had a major impact on the distribution of litter. There were significant differences in the cover of persistent litter across the 3 treatments $(P<0.01)$, with a decline from burned-unseeded (comprising mainly dead annual grasses), through control (sagebrush stems and leaves) to the burned-seeded (burned sagebrush and assorted dead bunchgrasses) treatments. Cover of non-persistent litter was very sparse in all treatments, but significantly less in the burned-unseeded treatment (Table 1).

\section{Soil crust cover and floristics}

Both lichen species richness and the total number of species were greatest on the control ( 35 species), least on the burned-unseeded ( 5 species) and intermediate on the burned-seeded ( 25 species) plots (Tables 2 and 3). The number of moss species was similar between treatments with 7,8 , and 5 in the control, burned-seeded and burned-unseeded treatments respectively. Riccia glauca, the only liverwort collected during the study, was found at one of the control sites only.

Fifteen lichen and 1 liverwort species were found only at the control sites, and 5 lichen and one moss species only at the burned-seeded plots (Table 2). The MDS ordination indicated that, overall, sites were very similar in their complement of species (Fig. 1). Analyses of similarities indicated no effect of either burning (Global $\mathrm{R}=0.13, \mathrm{P}=0.274$ ) nor seeding (Global $R=-0.031, P=0.488$ ) on the community structure of biological crust taxa. This lack of a burning or seeding effect was probably due to the small amount of replication $(n=3)$ and the type of data collected. Had we collected data on species abundance rather than just presence-absence, there may well have been significant burning and/or seeding effects.

\section{Changes in morphological groups}

There was significantly greater total lichen cover on the control plots compared with either the burned-unseeded or burned-seeded plots $\left(\mathrm{F}_{2,45}=21.9, \mathrm{P}<\right.$ $0.01)$.There were also significant differences in the cover of the various morphological groups (Table 4). The cover of all morphological groups of lichens was significantly greater on the control plots compared with the other plots $(P<0.01)$. The fruticose-foliose morphological group was the most abundant, consisting entirely of the fruticose species Aspicilia reptans and Aspicilia filiformis and the minute foliose species Cladonia pocillum (Table 2). These species are generally slower to recolonise burned sites.

The lichens recorded from the open areas of the cheatgrass canopy are species which are well-adapted to disturbed environments. Both Caloplaca tominii and Ochrolechia inaequatula have specialized structures for asexual reproduction which probably enhance their ability to disperse into disturbed sites. Cladonia pocillum occurs predominantly in the foliose form but occasionally produces fruticose structures. It disperses effectively by fragmen- tation (Ahti 1982), and fragments are able to lodge within relatively moist microsites at the edge of shrub canopies and under bunchgrass canopies where it thrives in association with short mosses. The moist environment created by the cheatgrass canopy, and later the short moss in the unseeded treatment, probably created a favourable environment for Cladonia pocillum.

In our study, the cover of the short moss group was consistently high across all treatments (Table 4), and increased significantly with the degree of disturbance, reaching maximum cover on the burnedseeded plots $\left(F_{2,45}=291.3, P<0.001\right)$. Short mosses such as Funaria hygrometrica and Ceratodon purpureus are fire increasers which are common on burned sites, often colonising burned organic material. They are also known to form associations with epiphytic cyanobacteria and non-symbiotic heterotrophic bacteria which might be important for nitrogen fixation following fire (During and von Tooren 1990). Depending on light and moisture levels, a Nostoc-Ceratodon purpureus association is capable of nitrogen fixation rates of $25-110 \mathrm{ng} \mathrm{N} \mathrm{g}^{-1}$ dry matter (Vlassak et al. 1973). While this is lower than that observed for a Nostocdominated microbiotic crust community (Belnap 2001), the contribution of nitrogen by a continuous moss cover could be significant in nutrient-deprived environments, particularly after burning. In addition to their role in soil nutrition, short mosses also play an important role in soil stabilization (Eldridge 1998).

Predictably, the cover of tall mosses was greatest on the control plots (34.8\%) and least on the 2 burned treatments (mean = $1.5 \% ; F_{2,45}=9.74, P<0.01$, Table 4). Tortula ruralis the dominant tall moss, is generally restricted to sheltered microsites beneath shrub and grass canopies (Rosentreter 1994) where it forms extensive mats on the soil surface. Tortula ruralis is well adapted to periodical and prolonged desiccation (Longton 1988) and is often dry below shrub canopies during mid-summer when the vegetation is also extremely dry and the chance of wildfires is greatest. Fire intensity is high under shrub canopies, due in part to high fuel loads contributed by dead sagebrush twigs, as well as litter under the shrubs (Blank et al. 1995) and annual plants growing on shrub hummocks. Consequently, the moss is destroyed and requires a long time period for recovery to full cover levels. Its occupation of moist sub-canopy microsites probably extends 
Table 2. Lichens and bryophytes (mosses and liverworts) found on the 3 treatments; * present, - not recorded. Lichen nomenclature follows Esslinger and Egan (1995), Rosentreter (1998), and McCune et al. (2002). Bryophyte nomenclature follows Anderson et al. (1990).

\begin{tabular}{|c|c|c|c|c|}
\hline Species & Type & Control & $\begin{array}{l}\text { Burned- } \\
\text { unseeded }\end{array}$ & $\begin{array}{l}\text { Burned- } \\
\text { seeded }\end{array}$ \\
\hline Bryum argenteum $\mathrm{Hedw}$. & Moss & * & * & * \\
\hline Bryum lisae De Not. & Moss & * & * & * \\
\hline Crossidium aberrans Holz. \& Bartr. & Moss & $*$ & $*$ & * \\
\hline Funaria hygrometrica Hedw. & Moss & * & * & * \\
\hline Pterygoneurum ovatum (Hedw.) Dix. & Moss & * & * & * \\
\hline Acarospora schleicheri (Ach.) A. Massal. & Lichen & * & - & * \\
\hline Aspicilia terrestris Tomin & Lichen & * & - & * \\
\hline Caloplaca tominii Savicz & Lichen & * & - & * \\
\hline Chromatochlamys muscorum (Fr.) H. Mayrh. \& Poelt var. octosporum (Nyl.) & Lichen & * & - & * \\
\hline Cladonia pocillum (Ach.) Grognot & Lichen & * & - & * \\
\hline Collema tenax Sw. Ach. & Lichen & * & - & * \\
\hline Didymodon rigidulus Hedw. & Moss & * & - & * \\
\hline Diploschistes muscorum (Scop.) R. Sant. & Lichen & * & - & * \\
\hline Endoarpon pusillum Hedwig & Lichen & * & - & * \\
\hline Lecanora muralis (Schreber) Rabenh. & Lichen & * & - & * \\
\hline Placyuthium squamulosum (Ach.) Breuss & Lichen & * & - & * \\
\hline Psora globifera (Ach.) Massal. & Lichen & * & - & * \\
\hline Tortula ruralis (Hedw.) Gaertn. et al. & Moss & * & - & * \\
\hline Amandinea punctata (Hoffm.) Coppins \& Scheid. & Lichen & * & - & - \\
\hline Arthonia glebosa Tuck. & Lichen & * & - & - \\
\hline Aspicilia filiformis Rosentreter & Lichen & * & - & - \\
\hline Aspicilia reptans (Looman) Wetmore & Lichen & * & - & - \\
\hline Candelariella terrigena Räsänen & Lichen & * & - & - \\
\hline Lecidea sp. Ach. & Lichen & * & - & - \\
\hline Leptochidium albociliatum (Desmaz.) Choisy & Lichen & $*$ & - & - \\
\hline Massalongia carnosa (Dickson) Körber & Lichen & * & - & - \\
\hline Ochrolechia inaequatula (Nyl.) Zahlbr. & Lichen & * & - & - \\
\hline Physcia dimidiata (Arnold) Nyl. & Lichen & * & - & - \\
\hline Psora cerebriformis W. A. Weber & Lichen & * & - & - \\
\hline Psora montana Timdal & Lichen & * & - & - \\
\hline Psora tuckermanii R. Anderson ex Timdal & Lichen & * & - & - \\
\hline Riccia glauca L. & Liverwort & * & - & - \\
\hline Leptogium lichenoides (L.) Zahlbr. & Lichen & * & - & - \\
\hline Trapeliopsis steppica McCune \& Camacho & Lichen & * & - & - \\
\hline Polychidium muscicola (Sw.) Gray & Lichen & * & - & * \\
\hline Candelaria concolor (Dickson) Stein & Lichen & - & - & * \\
\hline Collema coccophorum Tuck. & Lichen & - & - & $*$ \\
\hline Physcia magnussonii Frey & Lichen & - & - & * \\
\hline Placynthiella uliginosa (Schrader) Coppins \& P. James & Lichen & - & - & * \\
\hline Thrombium epigaeum (Pers.) Wallr. & Lichen & - & - & * \\
\hline Ceratodon purpureus (Hedw.) Brid. & Moss & - & - & $*$ \\
\hline
\end{tabular}

the time over which photosynthesis and other physiological functions occur. Full recovery of Tortula ruralis is probably restricted by the absence of the typically umbrella-shaped canopy of the sagebrush.

Funaria hygrometrica, an annual moss species, was a common component of the sqil surface at the burned-unseeded plots, and along with Ceratodon purpureus tends to invade burned sites rapidly after fire (Hoffman 1966, Southorn 1977). It responds rapidly to high nitrate nitrogen

Table 3. Mean diversity (no. of species) and richness (Margalef's index) of biological crust taxa on the 3 treatments. SE = standard error of the mean. Different letters within a row indicate a significant difference at $\mathrm{P}<0.05$.

\begin{tabular}{|c|c|c|c|c|c|c|}
\hline & \multicolumn{2}{|c|}{ Control } & \multicolumn{2}{|c|}{ Burned-unseeded } & \multicolumn{2}{|c|}{ Burned-seeded } \\
\hline & Mean & SE & Mean & $\mathrm{SE}$ & Mean & SE \\
\hline Number of species & $24.0^{\mathrm{a}}$ & 2.6 & $5.7^{b}$ & 1.5 & $14.3^{\mathrm{c}}$ & 5.1 \\
\hline Richness & $7.2^{\mathrm{a}}$ & 0.6 & $2.7^{\mathrm{b}}$ & 0.5 & $5.0^{\mathrm{c}}$ & 1.2 \\
\hline
\end{tabular}

and phosphorus concentrations present in post-burn soils (Southorn 1977), but declines in abundance due to competition for nutrients, water and light (Hoffman 1966, Longton 1988). The spores of Funaria hygrometrica can remain viable for more than a decade (Hoffman 1970), and its ability to grow under conditions of low light enables it to invade disturbed habitats (Young et al. 1987). Consequently, Funaria hygrometrica thrives in annual grass stands and other disturbed sites due in

part to its prolific spore production and tolerance of low light levels.

Several of the mosses recorded in the control and seeded treatments are categorized as "colonists" in terms of During's (1979) life-history strategies (Longton 1988). Species such as Bryum argenteum and Ceratodon purpureus are cosmopoli$\tan$ and their broad ecological amplitude allows them to successfully inhabit environments where rainfall is strongly seasonal and annually unpredictable, such as the semi-arid shrub-steppe, and occupy later successional stages in the community. In this type of environment they might function as "perennial stayers", species that occupy stable environments (Longton 1988). Both species are perennial and reproduce from either spores or vegetative propagules. Both Bryum argenteum and Bryum lisae were the dominant mosses in the burned-seeded plots, establishing an 


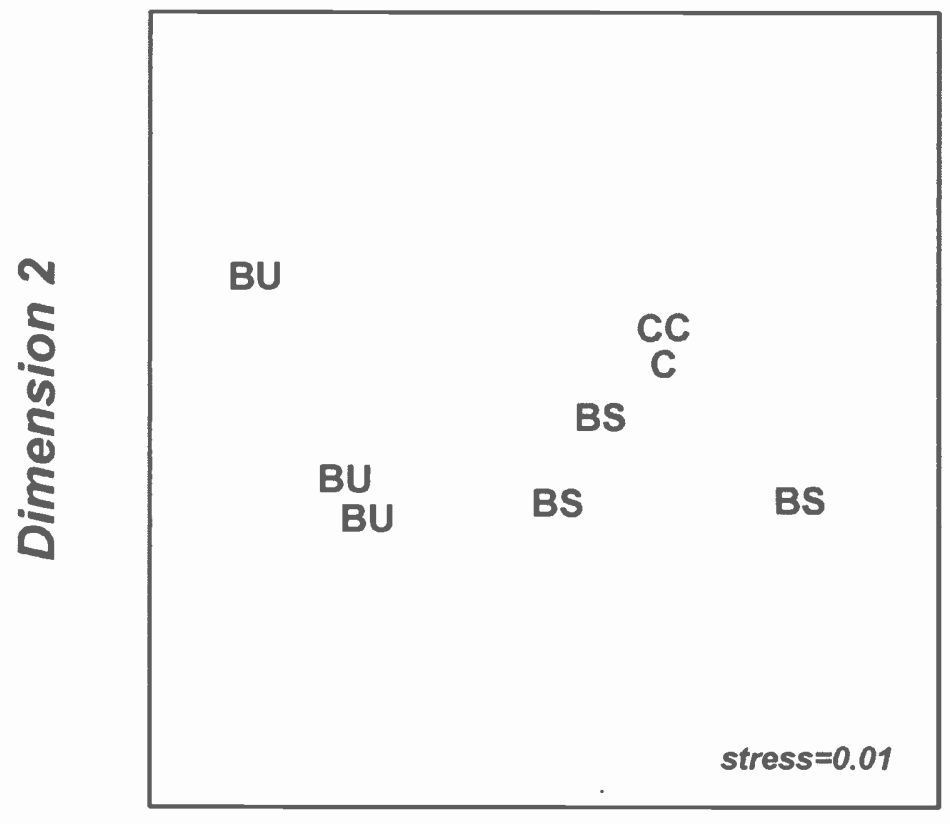

\section{Dimension 1}

Fig. 1. The first 2 dimensions of the Non Metric Multi-Dimensional Scaling biplot based on presence-absence of species, showing the relative positions of control (C), burned-seeded (BS) and burned-unseeded (BU) sites. Note the similarity of the control sites in terms of their complement of soil crust species.

almost continuous cover in some of the shrub interspaces.

\section{Crust and ecosystem recovery}

Recovery of the biological crust probably influences the succession of the vascular plant community following wildfire. Success of seed germination in a moss layer is partially dependent on morphological and physiological characteristics of both the seed and moss colony (Johnson and Thomas 1978, During and van Tooren 1990, van Tooren 1990). Once germination occurs, persistence of the juvenile plants in the moss mat might be enhanced by additional moisture and reduced temperature relative to bare ground (Johnson and Thomas 1978, van Tooren et al. 1988).

Native vascular plant species, which coexist with biological crusts in many arid and semi-arid regions, have adaptations which allow them to survive on a range of crust surface types from smooth surfaces where mucilaginous secretions are advantageous (Zaady et al. 1997) to roughened or cracking surfaces where hairs and hygroscopic awns are an advantage (Eckert et al. 1986). Germination of cheatgrass is known to be inhibited by light (Hulbert 1955), and the large, light-weight seeds require a degree of microrelief or disturbed (Larsen 1995, Howell 1998). The mechanism for this suppression of ference at $P<0.05$.

lichen and bryophyte cover only. germination in the presence of a crust is difficult to determine and most studies are only correlative. Reasons could relate to the a physical barrier to germination or reduced levels of soil-seed contact produced by moss or lichen plants (Jacques 1984), or to allelopathic effects on exotic species by organisms in the crust (sensu Zaady et al. 1997)

It seems likely that the combination of increased cover of seeded perennial grasses, and increased germination of small mosses responding to increased area of bare soil at the burned-seeded sites is responsible for the decrease in annual grasses. Some combination of competition from perennial grasses and the paucity of suitable sites for germination for annual grasses is also likely to have contributed to the reduced cover of annual grasses. However, the factors directly responsible for enhanced crust cover and reduced cover of annual grasses particularly Bromus tectorum, still needs to be determined by detailed field experiments.

\section{Management implications and conclusions}

Historically, Artemisia tridentata ssp. wyomingensis communities have burned at infrequent intervals (approximately every century or greater), resulting in a relatively stable shrubland-dominant plant community (Whisenant 1990). Despite the combined effects of both fire and disturbance by seeding, some recovery of biological crusts did occur in our study area. Our data suggest that some disturbance of the crust during the process of reseeding is preferable to no reseeding, as it provides greater control of annual grasses and ultimately allows the crust to recover in the absence of annual grasses. Reestablishment of landscape patchiness, with areas of shrubs separated from biological soil crustdominated interspaces is critical for the

Table 4. Crust cover, lichen cover and cover of individual morphological groups of lichens and mosses. $\mathrm{SE}=$ standard error of the mean. Different letters within a row indicate a significant dif-

\begin{tabular}{|c|c|c|c|c|c|c|}
\hline & \multicolumn{2}{|c|}{ Control } & \multicolumn{2}{|c|}{ Burned-unseeded } & \multicolumn{2}{|c|}{ Burned-seeded } \\
\hline & Mean & SE & Mean & SE & Mean & SE \\
\hline & & & & er $(\%$ & & \\
\hline Total crust cover' & $66.0^{\mathrm{a}}$ & 2.81 & $34.8^{\mathrm{b}}$ & 6.04 & $45.8^{c}$ & 4.74 \\
\hline Total lichen cover & $8.1^{\mathrm{a}}$ & 0.70 & $0.01^{\mathrm{b}}$ & 0.01 & $0.8^{\mathrm{b}}$ & 0.35 \\
\hline Short mosses & $23.1^{\mathrm{a}}$ & 4.12 & $34.0^{b}$ & 6.25 & $42.9^{c}$ & 3.14 \\
\hline Tall mosses & $34.8^{\mathrm{a}}$ & 1.06 & $0.8^{b}$ & 0.51 & $2.1^{b}$ & 1.67 \\
\hline Squamulose lichens & $0.6^{\mathrm{a}}$ & 0.01 & $0.0^{\mathrm{b}}$ & 0.00 & $0.0^{\mathrm{b}}$ & 0.12 \\
\hline Crustose lichens & $1.8^{\mathrm{a}}$ & 0.08 & $0.0^{b}$ & 0.00 & $0.2^{b}$ & 0.33 \\
\hline Gelatinous lichens & $1.5^{\mathrm{a}}$ & 0.07 & $0.0^{\mathrm{b}}$ & 0.00 & $0.2^{b}$ & 0.33 \\
\hline $\begin{array}{l}\text { Foliose-fruticose } \\
\text { lichens }\end{array}$ & $4.2^{\mathrm{a}}$ & 0.28 & $0.0^{b}$ & 0.01 & $0.4^{b}$ & 0.39 \\
\hline
\end{tabular}


maintenance of key ecosystem processes such as infiltration (Reid et al. 1999), and provides habitat for shrub obligate species (Yensen et al. 1992). Our observations suggest that these plant-free, relatively open interspaces are important to the recovery of biological soil crusts, particularly the lichen component, as lichens are restricted to these interspaces.

The development of biological soil crusts is retarded by both fire and disturbance, and their interactions (Kaltenecker et al. 1999). The combination of disturbance (particularly overgrazing) and fire leads to a dominance by exotic annual grasses, increasing the frequency of range fires and leading to further reduced levels of crust cover. Invasion by exotic annual grasses may permanently alter the biological crust community (Johansen 2001). Annual grass invasion increases plant density, reducing spatial heterogeneity in the shrub-steppe community (Mack 1981, Yensen et al. 1992) and eliminating the interspaces (Whisenant 1990), the preferred habitat for biological crusts and their associated taxa.

In our study, recovery of mosses and lichens in the unseeded treatments was limited by accumulation of Bromus tectorum litter (Table 1), particularly when litter depth exceeded about $1 \mathrm{~cm}$. Although this litter and annual plant cover provide protection to the soil surface, they are transient and when removed by periodic wildfire, surfaces are often exposed to soil and nutrient loss. This litter also prevents ecosystem recovery by giving exotic grasses such as cheatgrass a competitive advantage over native perennial grasses (Evans and Young 1984, Kaltenecker et al. 1999) further exacerbating the cycle of fire and shrubland collapse.

Revegetation results in a temporary disturbance of the soil surface, which, in degraded sites, is necessary to promote grass establishment and therefore the development of an roughened surface (Hilty et al. 2003). Our study has demonstrated that the biological soil crust will recover from disturbance, albeit slowly, and perhaps not fully, after range reseeding. Our field observations of sites in southern and eastern Idaho indicate that reseeding is likely to be most effective where post-revegetation impacts such as livestock trampling and grazing are minimal (Tables 3 and 4). Results from fire rehabilitation seedings carried out under the Green Stripping program indicate that the seeding of grasses provides a degree of resilience to repeated fire as well as creating a roughened soil surface. In areas where there is only limited vegetation disturbance, wildfire is likely to have a reduced impact on biological soil crusts due to the discontinuity of fuel. Our field observations at this and other sites in the Snake River Plain suggest that sites with an extensive, intact cover of biological soil crust in the interspaces tend to have a sparser cover of Bromus tectorum. Future studies of fire, biological soil crusts and invasion by annual exotic weeds aim to explore the links between intact crust surfaces and their impact on the germination and establishment of exotic plants.

\section{Literature Cited}

Ahti, T. 1982. Evolutionary trends in cladoniiform lichens. J. Hattori Botan. Lab. 52: 331-341.

Anderson, L.E., H.A. Crum, and W.R. Buck. 1990. List of the mosses of North America north of Mexico. Bryol. 93: 448-499.

Belnap, J. 2001. Factors influencing nitrogen fixation and nitrogen release in biological soil crusts. pp. 241-262. In: J. Belnap and O. Lange (eds.) Biological soil crusts: structure, management and function. Ecological Studies 150. Springer-Verlag Berlin.

Belnap, J. and D.J. Eldridge. 2001. Disturbance and recovery of biological soil crusts. pp. 363-384. In: J. Belnap and O. Lange (eds.) Biological soil crusts: structure, management and function. ecological studies 150. Springer-Verlag Berlin.

Bergkamp, G. 1998. A hierarchical view of the interactions of runoff and infiltration with vegetation and microtopography in semiarid shrublands. Catena 33:201-220.

Beymer, R.J. and J.M. Klopatek. 1991. Potential contribution of carbon by microphytic crusts in pinyon-juniper woodlands. Arid Soil Res. and Rehab. 5:187-198.

Blank, R.R., J.A. Young, and F.L. Allen. 1995. The soil beneath shrubs before and after wildfire: implications for revegetation, pp. 173-177. In: B.A. Roundy, E.D. McArthur, J.S. Haley and D.K. Mann (comps.) Proc. wildland shrub and arid land restoration symposium. General Technical Report INT-GTR-315. USDA Forest Service.

Brotherson, J.D., S.R. Rushforth, and J.R. Johansen. 1983. Effects of long-term grazing on cryptogam crust cover in Navajo National Monument, Arizona. J. Range Manage. 35:579-581.

Callison, J., J.D. Brotherson, and J.E. Brown. 1985. The effects of fire on the blackbrush (Coleogyne ramisissima) community of southwestern Utah. J. Range Manage. 38:535-538.

Canfield, R.H. 1941. Application of line interception in sampling range vegetation. J. Forest. 33:388-394.

Clarke, K.R. 1993. Non-parametric analyses of changes in community structure. Aust. J. Ecol. 18:117-143.
Clarke, K.R. and R.M. Warwick. 1994. Change in marine communities: an approach to statistical analysis and interpretation, Natural Environment Research Council, UK.

During, H.J. 1979. Life strategies of bryophytes: a preliminary review. Lindbergia 5: 2-18.

During, H.J. and B.F. van Tooren. 1990. Bryophyte interactions with other plants. Botan. J. Linn. Soc. 104:79-98.

Eckert, R.E. Jr., F.F. Peterson, M.S. Meurisse, and J.L. Stephens. 1986. Effects of soil-surface morphology on emergence and survival of seedlings in big sagebrush communities. J. Range Manage 39: 414-420.

Eldridge, D.J. 1998. Trampling of microphytic crusts on calcareous soils and its impact on erosion under rainimpacted flow. Catena 33: 221-239.

Eldridge, D.J. and R. Rosentreter. 1999. Morphological groups: a framework for monitoring microphytic crusts in arid landscapes. J. Arid Environ. 41:11-25.

Eldridge, D.J. and R. Simpson. 2001. Rabbit (Oryctolagus cuniculus L.) impacts on vegetation and soils, and implications for management of wooded rangelands. Basic Appl. Ecol. 3:19-29.

Esslinger, T.L. and R.S. Egan. 1995. A sixth checklist of the lichen-forming, lichenicolous, and allied fungi of the continental United States and Canada. Bryol. 98: 467-549.

Evans, R.A. and J.A. Young. 1970. Plant litter and establishment of alien annual weed species in rangeland communities. Weed Sci. 18:697-703.

Evans, R.A. and J.A. Young. 1984. Microsite requirements for downy brome (Bromus tectorum) infestation and control on sagebrush rangelands. Weed Sci. 32:13-17.

Gee, G.W. and J.W. Bauder. 1986. Particlesize analysis. pp. 383-411. In: A. Klute (ed.) Methods of soil analysis. American Society of Agronomy, Inc. and Soil Sci. Soc. of Amer. Madison, Wisc.

Greene, R.S.B., C.J. Chartres, and K.C. Hodgkinson. 1990. The effects of fire on the soil in a degraded semi-arid woodland. I. Cryptogam cover and physical and micromorphological properties. Aust. J. Soil Res. 28:755-777.

Harper, K.T. and J. Belnap. 2001. The influence of biological soil crusts on mineral uptake by associated vascular plants. J. Arid Environ. 47:347-357.

Harper, K.T. and R.L. Pendleton. 1993. Cyanobacteria and cyanolichens: can they enhance availability of essential minerals for higher plants? Great Basin Nat. 53:59-72.

Hilty, J., D.J. Eldridge, R. Rosentreter, and M. Wicklow-Howard. 2003. Burning and seeding influence soil surface morphology in an Artemisia shrubland in southern Idaho. Arid Land Res. Manage. 17:1-11.

Hironaka, M., M.A. Fosberg , and A.H. Winward. 1983. Sagebrush-grass Habitat Types of Southern Idaho. University of Idaho Forest, Wildlife and Range Experiment Station Bull. No. 35. University of Idaho, Moscow, Ida. 
Hoffman, G.R. 1966. Ecological studies of Funaria hygrometrica Hedw. in eastern Washington and northern Idaho. Ecol. Monogr. 36:157-180.

Hoffman, G.R. 1970. Spore viability in Funaria hygrometrica. Bryologist 73:634-635.

Howell, W. 1998. Germination and establishment of Bromus tectorum L. in relation to cation exchange capacity, seedbed, litter, soil cover and water. Unpublished thesis, Prescott College, Prescott, Ariz.

Hulbert, L.C. 1955. Ecological studies of Bromus tectorum. Ecol. Monogr. 25:181-213.

Jacques, I.D. 1984. Self-revegetation of a sagebrush-bunchgrass community after surface blading by bulldozer. Unpublished M.S. thesis, Washington State University, Pullman, Wash.

Johansen, J.R. 2001. Impacts of fire on biological soil crusts. pp. 385-400. In: J. Belnap and O. Lange (eds.) Biological soil crusts: structure, management and function. ecological studies 150. Springer-Verlag, Berlin.

Johnson, C.D. and A.G. Thomas. 1978. Recruitment and survival of seedlings of a perennial Hieracium species in a patchy environment. Can. J. Bot. 56: 572-580.

Kleiner, E.F. and K.T. Harper. 1972. Environment and community organization in grasslands of Canyonlands National Park. Ecol. 53:299-309.

Kaltenecker, J.H., M.C. Wicklow-Howard, and R. Rosentreter. 1999. Biological soil crusts in three sagebrush communities recovering from a century of livestock trampling, pp. 222-226. In: E.D. McArthur, W.K. Ostler and C.L. Wambolt (comps.) Shrubland ecotones. RMRS-P-11. USDA Forest Service, Rocky Mountain Research Station, Ogden, Utah.

Kochert, M.N. and M. Pellant. 1996. Multiple use in the Snake River Birds of Prey Area. Rangelands 8: 217-220.

Larsen, K.D. 1995. Effects of microbiotic crusts on the germination and establishment of three range grasses. Unpublished thesis, Boise State University, Boise, Ida.

Lesica, P. and J.S. Shelly. 1992. Effects of cryptogamic soil crust on the population dynamics of Arabis fecunda (Brassicaceae). Am. Midl. Nat. 128: 53-60.

Leys, J.F. and D.J. Eldridge. 1998. Influence of cryptogamic crust disturbance to wind erosion on sand and loam rangeland soils. Earth Surf. Process. and Landf. 23: 963-974.

Longton, R.E. 1988. Life-history strategies among bryophytes of arid regions. J. Hattori Bot. Lab. 64:15-28.

Longton, R.E. 1992. The role of bryophytes and lichens in terrestrial ecosystems, pp. 32-76. In: J.W. Bates and A.M. Farmer (eds.) Bryophytes and lichens in a changing environment. Cambridge Press, Oxford.

Mack, R.N. 1981. Invasion of Bromus tectorum L. into western North America: an ecological chronicle. Agro-Ecosystems 7:145-165.

McCune, B., F. Camacho, and J. Ponzetti. 2002. Three new species of Trapeliopsis on soil in western North America. Bryologist 105:78-85.
Minitab 1997. References Manual, Release 10.1, Minitab Inc. State College, Penn.

Reid, K.D., B.P. Wilcox, D.D. Breshears, and L. MacDonald. 1999. Runoff and erosion in a piñon-juniper woodland: influence of vegetation patches. Soil Sci. Soc. Amer. J. 63: 1869-1879.

Rosentreter, R. 1994. Displacement of rare plants by exotic grasses. pp. 170-175. In: S.B. Monsen and S.G. Kitchen (comps.) Proc. Ecology and management of annual rangelands. Gen. Tech. Rep. INT-GTR-313, USDA Forest Service.

Rosentreter, R. 1998. Notes on the Aspicilia reptans Complex, with descriptions of two new species. In: M.G. Glenn, R.C. Harris, R. Dirig and M. S. Cole (eds.) Lichenologia thomsoniana. North American Lichenology in honor of John Thomson. Ithaca, N.Y.

Rosentreter, R. and J. Belnap. 2001. Biological soil crusts of North America. pp. 31-50. In: J. Belnap and O. Lange (eds.) Biological soil crusts: structure, management and function. Ecological studies 150. Springer-Verlag, Berlin.

Rosentreter, R. and D.J. Eldridge. 2002. Monitoring biodiversity and ecosystem function: grasslands, deserts and steppe. pp. 223-237. In: P.L. Nimis, C. Scheidegger and P.A. Wolseley (eds.) Monitoring with lichens ñ monitoring lichens. Kluwer, Netherlands.

Schulten, J.A. 1985. The effects of burning on the soil lichen community of a sand prairie. Bryologist 88:110-114.

Southorn, A.L.D. 1977. Bryophyte recolonization of burnt ground with particular reference to Funaria hygrometrica. II. The nutrient requirements of Funaria hygrometrica. J. Bryol. 9:361-373.

van Tooren, B.F. 1990. Effects of a bryophyte layer on the emergence of seedlings of chalk grassland species. Acta Ocologica $11: 155-163$.

van Tooren, B.F., J. den Hertog, and J. Verhaar. 1988. Cover, biomass and nutrient content of bryophytes in Dutch chalk grasslands. Lindbergia 14:47-54.

Vlassak, K., E.A. Paul, and R.E. Harris. 1973. Assessment of biological nitrogen fixation in grassland and associated sites. Plant and Soil 38:637-649.

Warren, S.D. and D.J. Eldridge. 2001. Biological soil crusts and livestock in arid regions: are they compatible? pp. 401-416. In: J. Belnap and O. Lange (eds.) biological soil crusts: structure, management and function. ecological studies 150 . Springer-Verlag, Berlin.

West, N. E. 1990. Structure and function of microphytic soil crusts in wildland ecosystems of arid and semi-arid regions. Adv. Ecol. Res. 20:179-223.

Whisenant, S.G. 1990. Changing fire frequencies on Idahoís Snake River Plains: ecological and management implications. pp. 4-10. In: E.D. McArthur, E.M. Romney, S.D. Smith and P.T. Tueller (comps.) Proc. Symposium on cheatgrass invasion, shrub die-off, and other aspects of shrub biology and management. Gen. Tech. Rep. INT-276. USDA Forest Service.
Williams, J.D., J.P. Dobrowolski, and N.E. West. 1995. Microphytic crust influence on interrill erosion and infiltration capacity. Trans. ASAE 38:139-146.

Yensen, E, Q.L. Quinney, K. Johnson, K. Timmerman, and K. Steenhof. 1992. Fire, vegetation changes and population fluctuations of Townsend's ground squirrels. Amer. Midl. Nat. 128: 299-312.

Young, J.A., R.A. Evans, R.E. Eckert, and B.L. Kay. 1987. Cheatgrass. Rangelands 9: 266-270.

Youtie, B., J. Ponzetti, and D. Salzer. 1999. Fire and herbicides for exotic annual grass control: effects on native plants and microbiotic soil organisms. pp. 590-591. In: D. Eldridge and D. Freudenberger (eds.) People and Rangelands: building the future. Proc. of the $\mathrm{VI}^{\text {th }}$ Internat. Rangeland Congr., Vol 2. Townsville, Queensland, Australia.

Zaady E, Y. Gutterman, and B. Boeken. 1997. The germination of mucilaginous seeds of Plantago coronopus, Reboudia pinnata and Carrichtera annua on cyanobacterial soil crust from the Negev Desert. Plant and Soil 190:247-252. 